\title{
Enhancement of GABA-Activated Membrane Currents in Aged Fischer 344 Rat Basal Forebrain Neurons
}

\author{
William H. Griffith and David A. Murchison \\ Department of Medical Pharmacology and Toxicology, College of Medicine, Texas A\&M University, College Station, \\ Texas 77843
}

\begin{abstract}
Changes in GABAergic systems have been widely documented during development. Similar changes might also occur during aging, but little information is currently available. Whole-cell and single-channel GABA $_{A}$-activated currents were studied in acutely dissociated basal forebrain neurons. An age-related increase in whole-cell GABA currents was observed in cells from aged (19-25 month) Fischer 344 rats. The GABA current from aged animals displayed a greater maximum response, with no change in $\mathrm{EC}_{50}$ or slope of the GABA response curve. $A$ reduction in use-dependent slow receptor desensitization was also observed in aged cells. Single-channel conductance and channel open time were unchanged with age, suggesting no alteration in the properties of single GABA channels. The benzodiazepine, midazolam, potentiated GABA currents to a greater degree in aged animals, consistent with previous reports of enhanced benzodiazepine activity with age. Ontogeny of the $\mathrm{GABA}_{\mathrm{A}}$ receptor/ion channel complex may continue through the stages of development, maturation, and aging.
\end{abstract}

[Key words: aging, GABA, benzodiazepine, basal forebraln, patch clamp, single channel]

$\gamma$-Aminobutyric acid (GABA) is the predominant inhibitory neurotransmitter in the CNS. In virtually every area of the brain, GABA activates heterooligomeric membrane receptors to open chloride ion channels and mediate fast inhibitory neurotransmission (see reviews, Bormann, 1988; Sivilotti and Nistri, 1991). Although the biophysical properties of these chloride channels have been studied in detail in developing and adult neurons, there are no quantitative descriptions of these channels in aged animals. An important question in neuroscience is whether ontogeny of neurotransmitter systems continues throughout adult life and late into aging.

Numerous studies have demonstrated significant alterations in the early development of many neurotransmitter systems, such as the cholinergic (Sakmann and Brenner, 1978; Fischbach and Schultze, 1980; Mishina et al., 1986) and glutamatergic ( $N$ methyl-D-aspartate) systems (Tsumoto et al., 1987; Ben-Ari et al., 1988; Kleckner and Dingledine, 1991; Hestrin, 1992). The GABA receptor/ion channel complex displays similar develop-

Received Aug. 17, 1994; revised Sept. 27, 1994; accepted Sept. 30, 1994.

This work was supported by NIH Grant AG07805. We thank Dr. Gerald D. Frye for helpful comments on the manuscript, Dr. Jcrome Trzeciakowski and Dr. Mike Davis for use of analysis software, and Mark Jasek.

Correspondence should be addressed to William $\mathrm{H}$. Griffith at the above address.

Copyright (C) 1995 Society for Neuroscience $0270-6474 / 95 / 152407-10 \$ 05.00 / 0$ mental changes. Expression of mRNAs encoding the $\mathrm{GABA}_{\mathrm{A}}$ receptor change during development (Gambarana et al., 1991; Laurie et al., 1992; Zhang et al., 1992), as do electrophysiological responses to GABA and inhibitory synaptic potentials (Mueller et al., 1984; Cherubini et al., 1991; Luhmann and Prince, 1991; Zhang et al., 1991).

In contrast to these well-defined and consistent developmental changes, reports of aging-related alterations in $\mathrm{G} \Lambda \mathrm{B} \Lambda$ ergic inhibitory processes are often controversial and the data conflicting. Decreased GABA levels have been reported in the medial septum (MS) of aged Fischer 344 rats (Banay-Schwartz et al., 1989) with an age-related impairment of inhibitory synaptic transmission reported in the lateral septum (Garcia and Jaffard, 1993). No age-related changes in total $\mathrm{GABA}_{\mathrm{A}}$ receptor binding or agonist affinity were seen in the hippocampus (Ruano et al., 1991; Wenk et al., 1991), and no age-related changes in hippocampal inhibitory synaptic potentials were observed (Potier et al., 1992). However, an increased postsynaptic sensitivity to GABA was reported in the hippocampus of aged rats (Lippa et al., 1981). Similarly, an increased responsiveness to GABA was observed in oocytes injected with mRNA from aged rats as compared to those injected with mRNA from young animals (Carpenter et al., 1992). These results suggest that properties of GABAergic systems may change with age in certain brain areas.

The purpose of the present study was to examine the biophysical properties of the $\mathrm{GABA}_{\mathrm{A}}$ receptor/ion channel complex in the medial septum/nucleus of the diagonal band of young ( 1 3-month) and aged (19-25-month) male Fischer 344 rats. Whole-cell and single-channel GABA-activated currents were $\mathrm{Cl}^{-}$dependent, bicuculline sensitive, and predictably modulated by zinc, lanthanum, pentobarbital, and midazolam. An agc-rclated increase in whole-cell GABA currents was observed, but no changes in the properties of single GABA channels were seen. There was also an age-related increase in the ability of midazolam to potentiate GABA currents. These results suggest that GABAergic systems continue to be modified during aging and that changes in inhibitory processes occur in the aging brain.

\section{Materials and Methods}

Experimental animal. Fischer 344 rats were obtained from Harlan, Inc. (Indianapolis IN, NIA breeding colony) and were from 1-25 months of age. Rats had free access to food and water and were maintained on a $12 \mathrm{hr}$ light/dark cycle. Only male rats were used for age-related statistical comparisons; however, data from 12 female rats (intermediate aged 13-17 months) were included in Figure 1, illustrating the heterogeneity of the response to GABA.

Acutely dissociated cells. Neurons of the medial septum/nucleus of the diagonal band were chosen for this study because this area of the brain contains both cholinergic and GABAergic neurons (Panula et al., 
1984). The GABAergic cells are both local interneurons and septohippocampal projecting neurons that control hippocampal information processing (Freund and Antal, 1988). Standard techniques were used to prepare brain slices of the medial septum/nucleus of the diagonal band (Griffith, 1988). Slices were microdissected to isolate only the septal/diagonal band region and then placed in an enzymatic solution containing trypsin (Sigma type XI, $0.6-0.8 \mathrm{mg} / \mathrm{ml}$ ) in a PIPES (1,4-piperazine-diethanesulfonic acid) buffer at $\mathrm{pH} 7,0$. The enzymatic treatment lasted for $60 \mathrm{~min}$ at approximately $35^{\circ} \mathrm{C}$ and in other respects was similar to that described by Kay and Wong (1986). Individual cells were mechanically dispersed onto a coverslip following gentle trituration through a series of fire-polished pipettes and viewed on the stage of an inverted microscope (Axiovert 35, Zeiss). The coverslip was rinsed with Alcian blue $(0.1 \%$, Sigma) to facilitate cell adhesion. Acutely dissociated cells were utilized between $2-10 \mathrm{hr}$ after isolation, and no clear difference in viability was noted over this time period. All experiments were conducted at room temperature $\left(22-25^{\circ} \mathrm{C}\right)$.

Electrical recording. Whole-cell and outside-out configurations of the patch-clamp recording technique were used (Hamill et al., 1981). Patch pipettes were pulled from 1.5 o.d. glass capillary tubing (\#7052, Garner Glass Co., Claremont, CA), coated with wax to reduce stray capacitance, and fire-polished to resistances of 2-10 M 2 . Data were collected using an Axopatch 200 (Axon Instr.) and the pClamp suite of programs. Cell capacitance was measured from the potentiometer used to zero the capacitance transients. This value of cell capacitance was used as a measure of cell size, and in most experiments, current values were expressed as current densities $(\mathrm{pA} / \mathrm{pF})$. Whole-cell and single-channel currents were filtered at 1 and $2 \mathrm{kHz}$, respectively $(-3 \mathrm{~dB}$, eight-pole lowpass filter, Frequency Devices) and sampled at 5-10 kHz. Unless otherwise stated, whole-cell $\mathrm{G} \Lambda \mathrm{B} \Lambda$ currents were recorded at a holding potential of $-60 \mathrm{mV}$ and were measured as the difference current from baseline immediately before drug application. Changes in standing leak current were corrected to the initial baseline. Voltage ranps $(-100$ to $+30 \mathrm{mV}$ ) were generated in some experiments to determine the reversal potential of the GABA-induced current.

Data analysis. Sequential concentration-response curves were generated by applying increasing concentrations of GABA $(0.3-100 \mu \mathrm{M})$ with washout periods of $1-4$ min between applications. Curves were fit using

$$
I / I_{\max }=\left[1+\left(\mathrm{EC}_{50} / A\right)^{n}\right]^{-1},
$$

where $I$ is the GABA induced current, $I_{\max }$ the maximal GABA current, $A$ the concentration of GABA (agonist), and $n$ the Hill coefficient or slope. Fits were obtained by a nonlinear regression using a maximum likelihood loss function. Only data that were fit with a correlation coefficient greater than 0.95 were included. Parameters were obtained for an individual cell and mean values were compared across age groups. Mean data from all sequential concentration-response curves were also graphed for comparison with nonsequential concentration-response curves. These latter curves were compiled from experiments where different agonist concentrations were applied in a random order.

Two measures of desensitization were studicd; (1) rapid desensitization during GABA application, and (2) slow desensitization of the GABA response that developed after repeated GABA applications. Rapid desensitization was measured as the ratio of the current remaining at the end of a 5 sec GABA application over the peak GABA current. Time constant measurements during this short application were quite variable and subject to error since steady-state current levels were never attained during this short application. Slow desensitization of the GABA response was expressed as the percent decline of the peak current amplitude with time.

Solutions and drugs. Cells in the recording chamber were continually perfused with the "normal" physiological solution consisting of (mM) $\mathrm{NaCl}, 140 ; \mathrm{KCl}, 3 ; \mathrm{CaCl}_{2}, 1 ; \mathrm{MgCl}_{2}, 2 ; \mathrm{D}$-glucose, 33; and HEPES, 10 (pH 7.4 with $\mathrm{NaOH})$. GABA and other drugs were applied in a modified physiological solution in order to maximize chloride currents and reduce sodium and potassium currents. This solution contained (mM) $\mathrm{NaCl}$, 132; $\mathrm{BaCl}_{2}, 2 ; \mathrm{MgCl}_{2}, 2$; D-glucose, 33; tetraethylammonium (TEA) chloride, 10; HEPES, 10; and tetrodotoxin (Calbiochem), $0.5 \mu \mathrm{M}(\mathrm{pH}$ 7.4; osmolarity $310-330 \mathrm{mOsm}$ ). The internal pipette solution contained in (mM) CsCl, 120; $\mathrm{MgCl}_{2}$, 2; TEA-Cl, 20; EGTA (Fisher), 10; GTP, 0.1; ATP, 4; and HEPES, 10 (pH 7.2 with $\mathrm{CsOH}$; osmolarity 280-300 mOsm). The liquid junction potential that existed between solutions was ( $3 \mathrm{mV}$ ) calculated using the program JPcalc (N. B. Datyner, Wellesley, MA) and was not adjusted. Midazolam was a gift from Hoffmann-
LaRoche. Pentobarbital was provided by S. B. Penick and Co. (NY). All other chemicals were obtained from Sigma, except as indicated.

Rapid drug application. GABA and drug solutions were applied to isolated cells via two glass pipettes $(500 \mathrm{~mm}$ i.d.) positioned adjacent to the recorded cell. Each pipette was attached via teflon tubing to a valve connecting it to one of six to eight different solution reservoirs. The first pipette was positioned directly over the neuron being recorded. A steady stream of drug-free solution prevented the drug-containing solution from the second pipette from diffusing to the cell. To apply GABA (or other drugs), the dual pipette assembly was rapidly moved $1 \mathrm{~mm}$, repositioning the drug stream immediately over the cell. After the desired application, the pipette assembly was returned to the starting position. Using this approach, rapid drug application $(<100 \mathrm{msec})$ could be achieved. Continual perfusion of the recording chamber further facilitated rapid removal of solutions.

Short periods of drug application $(5 \mathrm{sec})$ were used to reduce the unavoidable desensitization of the GABA response that develops with repeated applications. The longer applications (60 sec in Fig. 1) were used to illustrate the heterogeneity of the GABA current in these cells. Prior to experimental drug applications, cells were given short exposures of $0.3 \mu \mathrm{M}$ GABA in order to standardize the initial response.

\section{Results}

\section{Heterogeneity of $G A B A$ responses}

Membrane currents activated by rapid application of GABA $(0.3-100 \mu \mathrm{M})$ were studied in 126 neurons from 57 young rats (1-3 months) and 95 cells from 33 aged rats (19-25 months). Virtually all neurons responded to GABA, and cells exhibited a tremendous heterogeneity of GABA responses. In Figure $1 A$, increasing concentrations of GABA $(1-10 \mu \mathrm{M})$ produced the expected concentration-related increase in membrane current with development of rapid desensitization during the $60 \mathrm{sec}$ drug application in cells from both age groups. In contrast, Figure $1 B$ illustrates that the same concentrations of GABA generate different concentration response patterns in other cells. In these cells, $10 \mu \mathrm{M}$ GABA rapidly desensitized, such that the peak response is similar in amplitude to that of $3 \mu \mathrm{M}$. Importantly, such variation was evident within both age groups. Not only was current amplitude variable, but development of rapid desensitization was also variable. Note that $3 \mu \mathrm{M}$ GABA induced a more pronounced desensitization in the 1 month cell in Figure $1 B$ compared to the 2 month cell shown in Figure $1 A$.

In addition to heterogeneity in concentration-response and rapid desensitization mentioned above, Figure $1 C$ shows examples of variability within the same cell. Responses to low concentrations of GABA $(0.3-3 \mu \mathrm{M})$ usually remained constant over time or increased after intervening application of higher concentrations (Fig. 1C). The response to higher concentrations (10$100 \mu \mathrm{M}$ ) of GABA generally declined over time (Fig. 1C). Furthermore, there was no clear correlation between cell capacitance (i.e., size) and membrane current at any age, nor were agerelated changes in GABA current correlated to specific sized neurons (Fig. 1D).

\section{Age-related increase in maximum response}

Since the previous history of GABA application to a cell could influence subsequent current amplitudes, two experimental protocols were designed to assess the impact of this use-dependent variability on the results (see Materials and Methods). "Sequential" concentration-response curves were generated from protocols using increasing concentrations of agonist followed by 14 min washout periods increasing with GABA concentration. In this protocol, the use-dependent history of the cells was standardized. Typical sequential concentration-response curves are shown in Figure 2 . Currents generated by $5 \mathrm{sec}$ GABA applications are shown for cells from a young (1.5-month) and an 


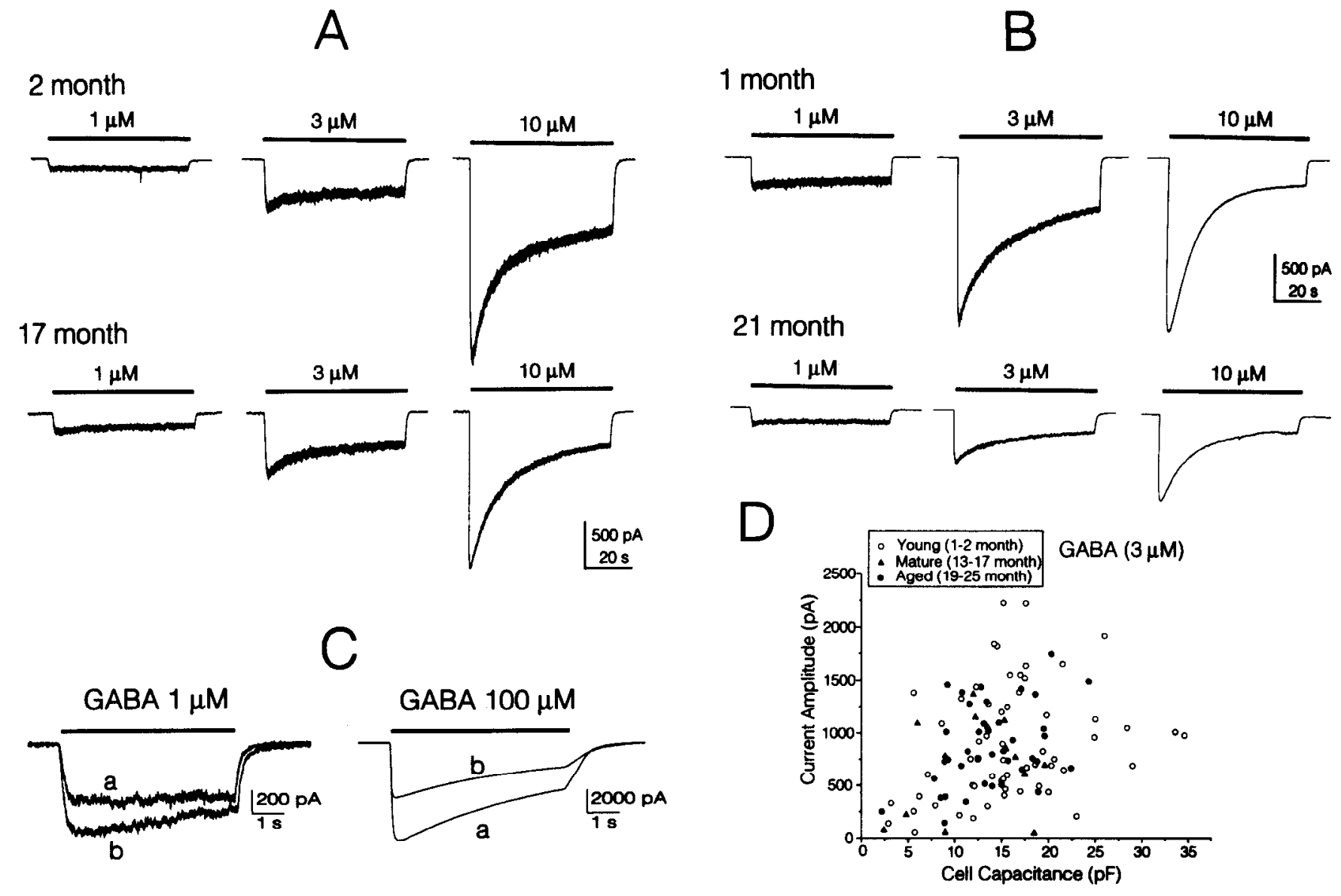

Figure 1. Heterogeneity of $\mathrm{GABA}_{\mathrm{A}}$ responses. $A$, GABA (1-10 $\left.\mu \mathrm{M}\right)$ application to cells from different age groups. Note the concentrationresponse effects in both age groups. Holding potential $\left(V_{h}\right)$ was $-60 \mathrm{mV}$ in this figure and throughout. $B$, GABA (1-10 $\left.\mu \mathrm{M}\right)$ application to different cells. A greater degree of desensitization is shown at 3 and $10 \mu \mathrm{M}$, while the peak at $10 \mu \mathrm{M}$ is similar to that of $3 \mu \mathrm{M}$ (compare $A$ and $B$ ). $C$, Repeated GABA applications display changes over time. First $(a)$ and second $(b)$ applications are shown. Time between GABA application was $17 \mathrm{~min}$ for the cell on the left ( 17 month animal) and $10 \mathrm{~min}$ for the cell on the right ( 1 month animal). Low concentrations of GABA showed potentiated responses after intervening applications of higher concentrations, while responses to higher concentrations decreased on second application due to desensitization. $D$, Graph of current amplitude versus cell capacitance (i.e., size) for different age groups.

aged (20-month) animal. Analysis of the curves indicate GABA elicited a greater maximal response with no change in $\mathrm{EC}_{50}$ or slope in the aged cell.

Composite sequential concentration-response curves are shown in Figure 3A. A statistically significant difference ( $p<$ 0.05 , two-tailed independent $t$ test) was observed at the three highest GABA concentrations. Sequential concentration-response data are summarized in Table 1. Each cell included in Figure 3 was individually analyzed, with $\mathrm{EC}_{50}$, slope, and maximum response being determined from Eq. (1) (see Materials and Methods). Only curves that were fit with correlation coefficients greater than 0.95 (least squares fit) and received at least five sequential GABA concentrations were included in the analyses. No statistical difference between the $\mathrm{EC}_{50}$ or slope was observed. Only the maximum current changed with age, showing an increase from $192.2 \pm 39.0$ to $488 \pm 94.7 \mathrm{pA} / \mathrm{pF}$ (Table 1). These data suggest a change in the maximum efficacy without change in receptor affinity or cooperativity with age.

Qualitatively similar results were obtained when data from "nonsequential" application protocols were examined (Fig. 3B). In these cells, GABA concentrations were applied in more or less random order with higher concentrations of GABA often preceding lower concentrations. Random application of the var- ious GABA concentrations to a large number of cells minimizes use-dependent effects on the shape of the response curves. As in the sequential protocol, the concentration-response curve is shifted upward in aged cells with significant differences between ages observed at 10 and $30 \mu \mathrm{M}$ GABA (Fig. $3 B$ ). The $\mathrm{EC}_{50}$ and slope of the curves were not different.

Since GABA-induced membrane currents display use-dependent modulation and show pronounced receptor desensitization (Fig. 1), changes in either or both of these factors could contribute to the enhanced whole-cell current recorded in aged cells. For example, a decrease in rapid desensitization in aged cells may be reflected as an enhanced whole-cell current. We compared rapid desensitization in both age groups during $5 \mathrm{sec}$ GABA applications. The amplitudes of the GABA-induced current at the peak $\left(I_{\max }\right)$ and end of the $5 \mathrm{sec}$ application $(I)$ were compared for the same data set used in the sequential concentration-response analysis. The ratio $I / I_{\max }$ decreased as the concentrations of GABA were increased but displayed no age-related difference (Table 1). Therefore, reduction of rapid receptor desensitization could not explain the increased whole-cell GABA current observed with age.

A second mechanism that could contribute to the observed changes in whole-cell current is use-dependent modulation in 
A

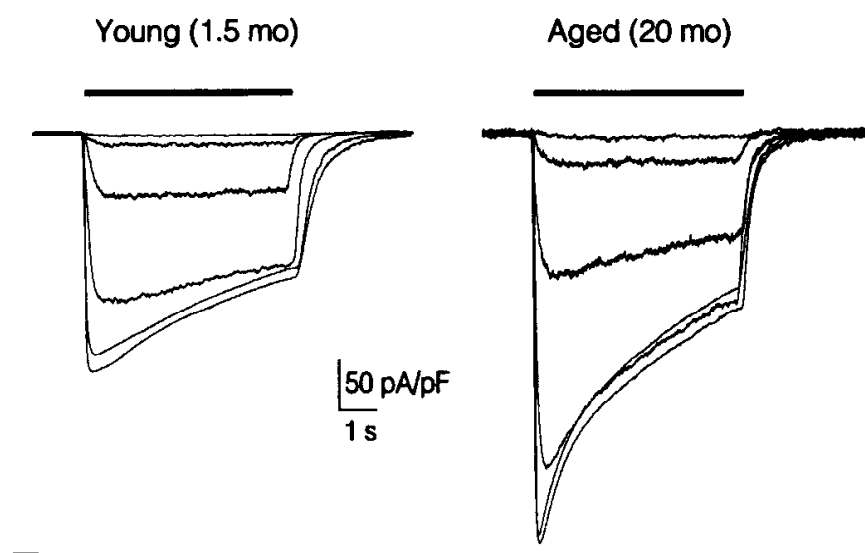

B

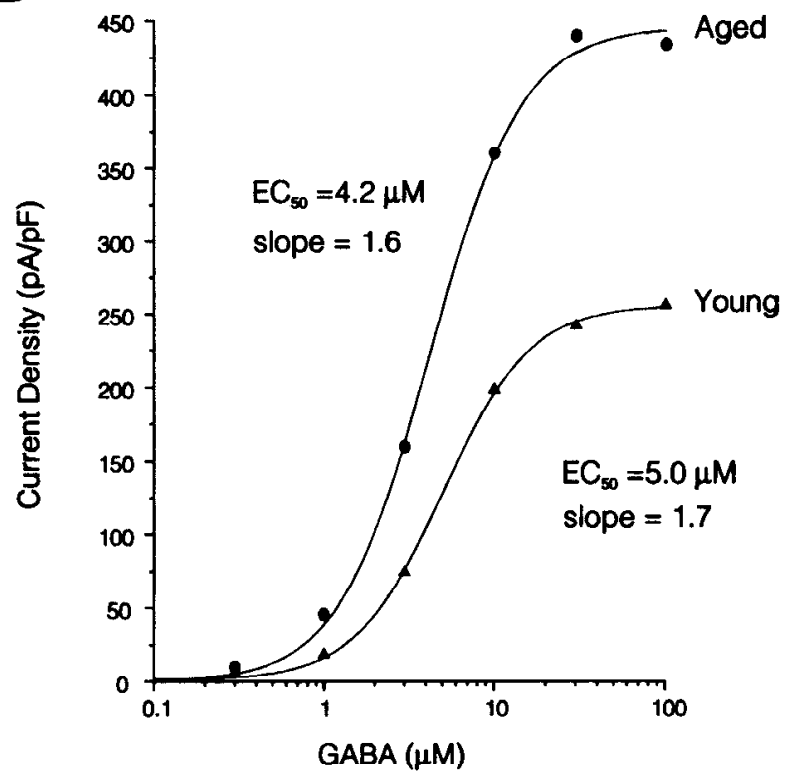

Figure 2. Whole-cell GABA currents increase with age. A, Normalized whole-cell currents generated by GABA $(0.3-100 \mu \mathrm{M})$. GABA was applied for 5 sec (during bar) in cells from a young ( 1.5 month) and aged (20 month) rat. $B$, Concentration-response curves for the two cells shown in $A$. Only the maximum response was increased in the cell from the aged animal (20 month).

the form of slow desensitization of the GABA current. Rundown of the GABA response was prevented by the inclusion of ATP/GTP, $\mathrm{Mg}^{2+}$, and EGTA in the pipette (Chen et al., 1990). Whereas the sequential and nonsequential dose-response curves are nearly the same in the aged cells, the sequential curve is shifted downward from the nonsequential curve in the young, suggesting a more pronounced use-dependent effect in those cells. We, therefore, tested the time course of slow GABA desensitization in both age groups (Fig. 4). Repeated $5 \mathrm{sec}$ applications of GABA $(30 \mu \mathrm{M})$ were tested over a period of approximately $30 \mathrm{~min}$. A time interval of at least $3 \mathrm{~min}$ was allowed between GABA applications. In cells from young rats, GABA currents decreased to approximately $70 \%$ of their control value over a time course of 20-30 min. A significantly greater reduction was observed starting at 11-14 min in young rats. Conversely, there was very little mean decline of GABA currents in cells from aged animals (10\%). This could be explained by our unpublished observation that aged cells recover from slow desensitization more quickly than young cells.

The greater desensitization in young cells could be reflected in the large difference observed between the sequential concentration-response curves. Sequential concentration-response curves required at least $15 \mathrm{~min}$ to obtain all the desired data. At this time, high $(30 \mu \mathrm{M})$ GABA concentrations are already showing significant desensitization in young cells (Fig. 4). Decreased slow desensitization in aged cells could contribute to the striking difference observed in sequential concentration-response curves, but it cannot explain the difference seen in the nonsequential data.

\section{Pharmacological modulation of GABA currents}

GABA-induced membrane currents were predictably modulated by a number of agents previously shown to affect the GABA receptor/ion channel complex. GABA $(3 \mu \mathrm{M})$ was applied alone and then in the presence of modulators (Fig. 5). Lanthanum $\left(\mathrm{La}^{3+}, 300 \mu \mathrm{M}\right)$, pentobarbital $(10 \mu \mathrm{M})$, and the benzodiazepine midazolam $(1 \mu \mathrm{M})$ all increased GABA-induced currents. No age-related differences in the degree of enhancement were observed with $\mathrm{La}^{2+}$ or pentobarbital. However, midazolam produced a significantly larger increase in aged cells (Fig. 5B). This age-related enhancement was specific for midazolam since it was not observed with any of the other modulators. Interestingly, a change in modulator sensitivity with age may indicate a switch in the functional properties of the channel, as previously shown by Smart and Constanti (1990), for developmental changes in the GABA receptor/ion channel complex. Two negative modulators of the GABA receptor/ion channel complex were also examined. Zinc $(300 \mu \mathrm{M})$ and bicuculline $(30 \mu \mathrm{M})$ decreased GABA-induced currents (Fig. 5) in both age groups. There were no age-related differences in effects of these two compounds.

\section{Single-channel GABA currents}

Many properties of single GABA channels previously identified in other cell types were also present in basal forebrain neurons. Multiple subconductance states, rapid channel desensitization, and complex channel kinetics were all features of single GABA channels recorded from both young and aged animals. Figure 6 shows single-channel currents from a 24 -month animal. Subconductance levels of approximately 11 and 19 were often observed in addition to the main conductance state of $25 \mathrm{pS}$ (Fig. 6A). Similar subconductance levels were also observed in cells from young animals (data not shown). High concentrations of GABA $(30 \mu \mathrm{M})$ invariably induced rapid channel desensitization when applied continuously (Fig. 6B). The outside-out patch in this example had multiple channels that quickly desensitized to oneor two-channels opening. Such channel activity is well characterized for many neuron types; therefore, single GABA channels in basal forebrain neurons appear to have standard physiological properties.

No change in single-channel properties were observed with age. For the main unitary conductance level, slope conductances were $25.3 \pm 1.6 \mathrm{pS}$ in cells from young rats $(n=6)$ and 26.7 $\pm 1.4 \mathrm{pS}$ in aged cells $(n=5$; Table 1$)$. In Figure $7 B$, a single line best describes the slope conductances in young and aged cells. No change in the GABA reversal potential was observed (Table 1). Likewise, open channel kinetics were similar in both age groups. In Figure 7, $C$ and $D$ show channel open time histograms from patches from young and aged cells. Data was 

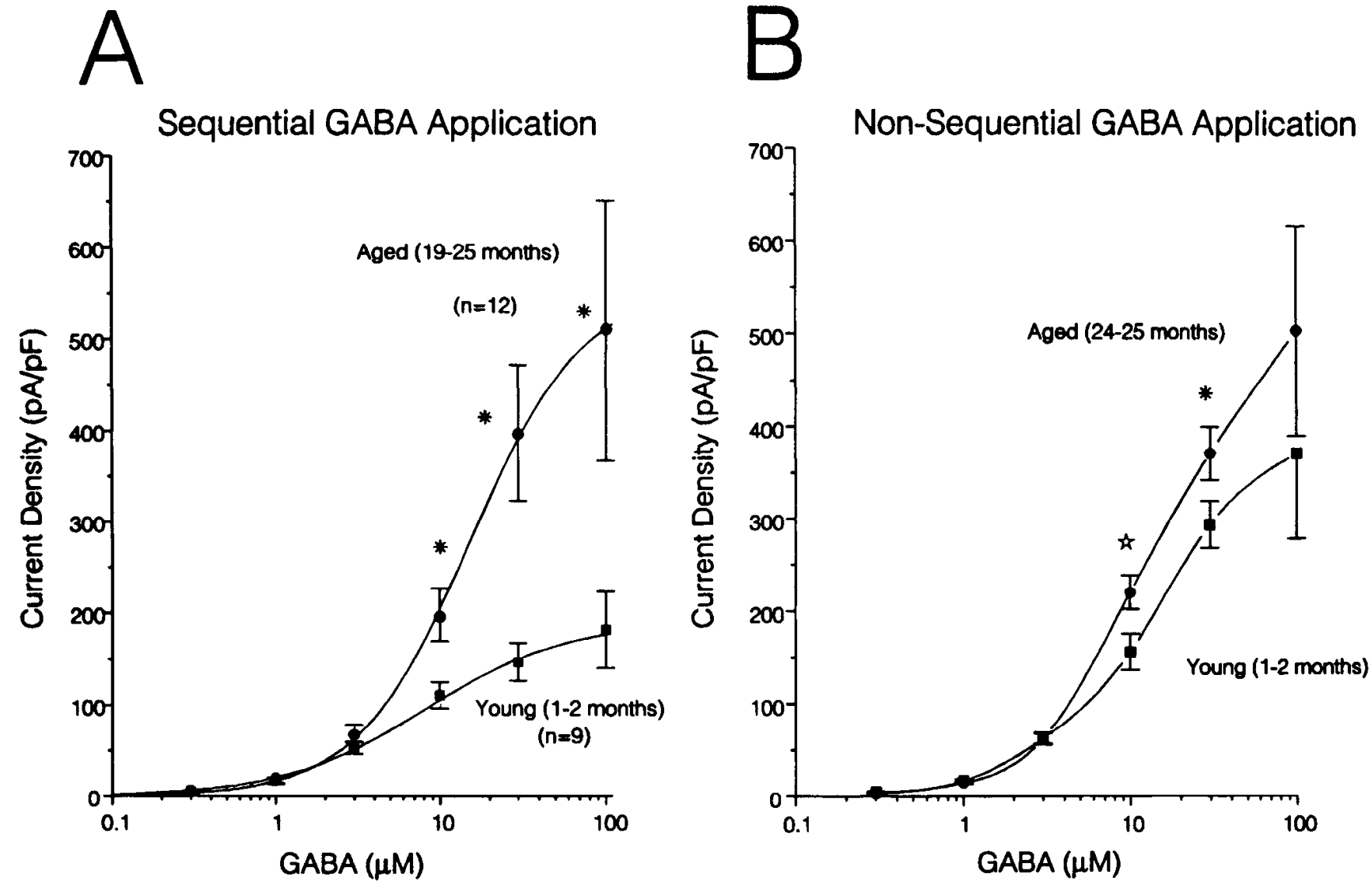

Figure 3. Comparison of concentration-response curves for different GABA application protocols. A, Concentration-response curves for those cells where sequential concentration-response curves were obtained (see Materials and Methods). GABA was applied in the order of lowest to highest concentration $\left({ }^{*} p<0.05\right.$, two-tailed $t$ test). $B$, Composite concentration-response curves from nonsequential protocols $(n=60$ aged, $n=$ 109 young). Not all cells received all concentrations, and high concentrations of GABA were often applied prior to lower concentrations. $\left({ }^{*} p<\right.$ 0.05 , two-tailed $t$ test; $\_p<0.05$, one-tailed $t$ test).

\begin{tabular}{|c|c|c|}
\hline & Aged & Young $^{a}$ \\
\hline \multicolumn{3}{|l|}{ Whole cell } \\
\hline \multicolumn{3}{|l|}{ Dose-response relationship } \\
\hline $\mathrm{EC}_{50}(\mu \mathrm{M})$ & $9.7 \pm 3.5(9)$ & $9.9 \pm 1.9(12)$ \\
\hline Slope & $1.7 \pm 0.2(9)$ & $2.1 \pm 0.2(12)$ \\
\hline$I_{\max }(\mathrm{pA} / \mathrm{pF})$ & $192.2 \pm 39.0(9)$ & $488.0 \pm 94.7(12)^{*}$ \\
\hline \multicolumn{3}{|c|}{$I / I_{\max }$ ratio for GABA $5 \mathrm{sec}$ application } \\
\hline $0.3 \mu \mathrm{M}$ & $0.98 \pm 0.01(9)$ & $0.98 \pm 0.03(12)$ \\
\hline $1.0 \mu \mathrm{M}$ & $0.93 \pm 0.02(9)$ & $0.97 \pm 0.02(12)$ \\
\hline $3.0 \mu \mathrm{M}$ & $0.85 \pm 0.03(9)$ & $0.86 \pm 0.02(12)$ \\
\hline $10 \mu \mathrm{M}$ & $0.70 \pm 0.03(9)$ & $0.68 \pm 0.04(12)$ \\
\hline $30 \mu \mathrm{M}$ & $0.55 \pm 0.04(9)$ & $0.45 \pm 0.06(12)$ \\
\hline $100 \mu \mathrm{M}$ & $0.51 \pm 0.06(9)$ & $0.44 \pm 0.09(7)$ \\
\hline \multicolumn{3}{|c|}{ Reversal potential for GABA $3 \mu \mathrm{M}$} \\
\hline$E_{\mathrm{Rev}}(\mathrm{IIIV})$ & $1.8 \perp 0.9(16)$ & $-0.7 \pm 0.9(19)$ \\
\hline \multicolumn{3}{|l|}{ Single channel } \\
\hline Unitary conductance $(\mathrm{pS})$ & $25.3 \pm 1.6(6)$ & $26.7 \pm 1.4(5)$ \\
\hline Reversal potential (mV) & $-2.1 \pm 2.2(6)$ & $-3.1 \pm 1.7(5)$ \\
\hline
\end{tabular}

Values are mean $\pm \mathrm{SE}$; numbers in parentheses indicate $n$ values; for ratio measurements, $I$ was defined as the current near the end of a $5 \sec$ GABA application, and $I_{\max }$ was the peak current.

a(Young refers to 12 months old; aged refers to 19-25 months old).

$* p<0.05$. pooled from three patches (4772 channel openings) in young (1-3-month) and three patches (6158 channel openings) in aged (24-25-month) animals. Both histograms were best fit with an exponential function utilizing three time constants, suggesting no age-related changes in open time kinetics. Since it was not possible to obtain a single isolated channel in the outside-out recording configuration, no estimate of closed time kinetics was determined.

\section{Discussion}

Aging is associated with numerous morphological and biochemical changes including alterations of neurotransmitter systems in the brain. It is now well established that embryonic and early postnatal rat $\mathrm{GABA}_{\mathrm{A}}$ receptors differ markedly from those in adult brain, both in terms of subunit composition (Laurie et al., 1992; Zhang et al., 1992) and pharmacology (Smart, 1992; Aguayo and Alarcon, 1993; Rovira and Ben-Ari, 1993). Changes in GABAergic mechanisms during senescence are less well documented. Our results indicate that ontogeny of $\mathrm{GABA}_{\mathrm{A}^{-}}$ mediated systems continues during development, maturation, and aging. The present experiments demonstrate an age-related increase in wholc-ccll GABA currents without changes in the properties of the unitary GABA channels. The pharmacological profile of the $\mathrm{GABA}_{\mathrm{A}}$ receptor also changed, as the benzodiazepine, midazolam, produced a greater potentiation of the GABA- 


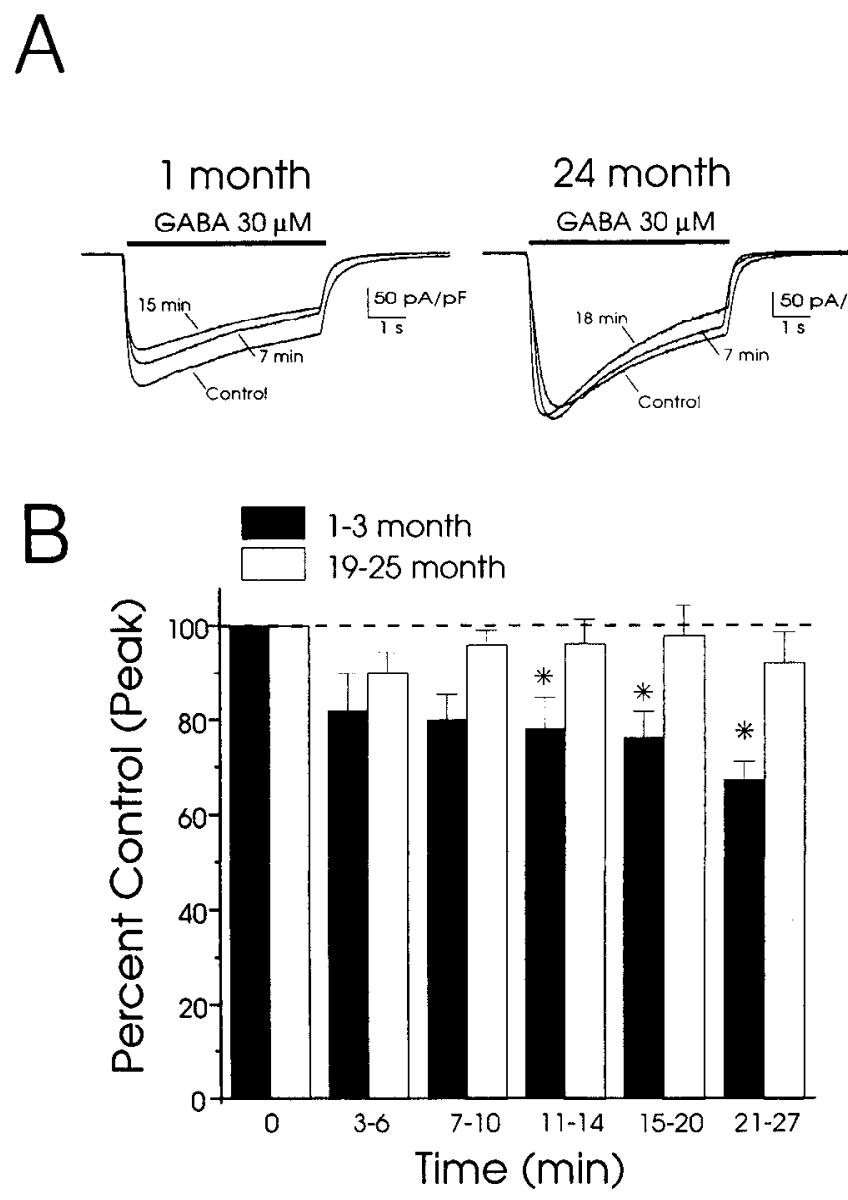

Figure 4. Time course of slow desensitization of GABA current. A, GABA $(30 \mu \mathrm{M})$ was reapplied at various times after the initial GABA application (Control). The cell to the left is from a young (1 month) animal, whereas the cell shown to the right is from an aged (24 month) animal. Note the time-dependent decline in current amplitude in the young but not the aged cell. $B$, Time course of the slow desensitization of GABA currents. Mean data for all experiments as shown in A. GABA $(30 \mu \mathrm{M})$ was applied at different time intervals after the initial GABA application (time 0). There was at least a $3 \mathrm{~min}$ interval between applications. $\left({ }^{*} p<0.05\right.$, two-tailed $t$ test; $n=5-25$ in young and 5-19 for aged).

mediated current in aged cells. These latter results suggest changes in the subunit composition or in allosteric interactions between the subunits of the receptor. The current amplitude increase could be explained by several mechanisms: first, GABA channels could continue to be expressed during aging, resulting in progressively more channels present in the membrane; second, the same number of channels could be present in a reduced area of membrane surface, thus producing an increased current density; third, receptor subunit composition could change with age such that ligand binding, channel kinetics, and/or ion specificity are altered; finally, second-messenger and intracellular systems that regulate phosphorylation and desensitization could change with age. Discovery of these changes may provide insight into some of the consequences of aging on brain function.

\section{Age-related changes in whole-cell GABA currents}

There are several plausible mechanisms by which whole-cell GABA-mediated currents might be increased in aged neurons. During development, GABA appears to mediate an increase in the number of its own receptors (Kim et al., 1993). The opera-
A
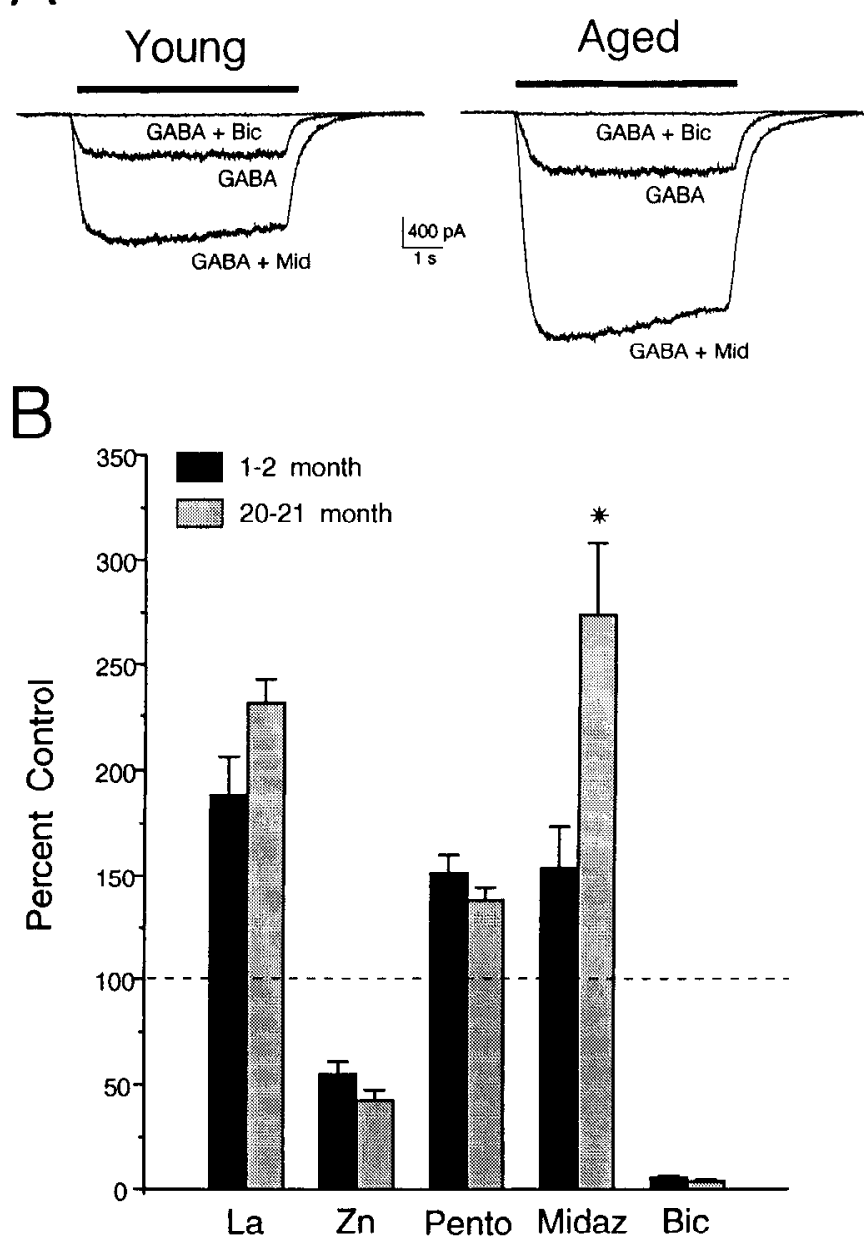

Figure 5. Age-related regulation of GABA currents by receptor modulators. $A, \mathrm{GABA}(3 \mu \mathrm{M})$ application (bar) to two different cells; first alone $(G A B A)$, second in the presence of midazolam $1 \mu \mathrm{M}(G A B A+$ Mid), and finally in the presence of bicuculline $30 \mu \mathrm{M}(G A B A+B i c)$. Note the greater percentage increase with midazolam in the aged cell (from a 20-month animal) as compared to the young (1 month) cell. $B$, Changes in GABA-activated currents caused by lanthanum $(L a, 300$ $\mu \mathrm{M})$, zinc $(\mathrm{Zn}, 300 \mu \mathrm{M})$, pentobarbitol (Pento, $10 \mu \mathrm{M})$, midazolam (Mid, $1 \mu \mathrm{M})$, and bicuculline $($ Bic, $30 \mu \mathrm{M})$. Results represent mean $\pm \mathrm{SE}(n$ $=9-13$ for each age group) of responses from cells tested with $3 \mu \mathrm{M}$ GABA alone and in combination with the modulator. $\left({ }^{*} p<0.05\right.$, twotailed $t$ test).

tion of such a process throughout ontogeny could result in a cumulative increase in the number of GABA receptors, and thus, the magnitude of GABA responses, with age. However, most data indicate no change or a decrease in receptor binding sites with age (Lippa et al., 1981; Concas et al., 1988; Erdo and Wolff, 1989; Mhatre and Ticku, 1992).

An age-related decrease in the size of basal forebrain neurons has been widely observed (review, Decker, 1987). Aged neurons in the present study were significantly smaller than young neurons, as judged by reduced-cell membrane capacitance (13.3 \pm 0.5 vs $17.0 \pm 0.6, p<0.05$, two-tailed $t$ test). This could be due to a selective loss of larger cells with age or to a general reduction in cell size because of a loss of membrane surface. If the latter possibility is true, then the age-related increase in whole-cell current density could be explained as the result of a stable number of receptors occupying a smaller area of mem- 
A

\section{Subconductance states}

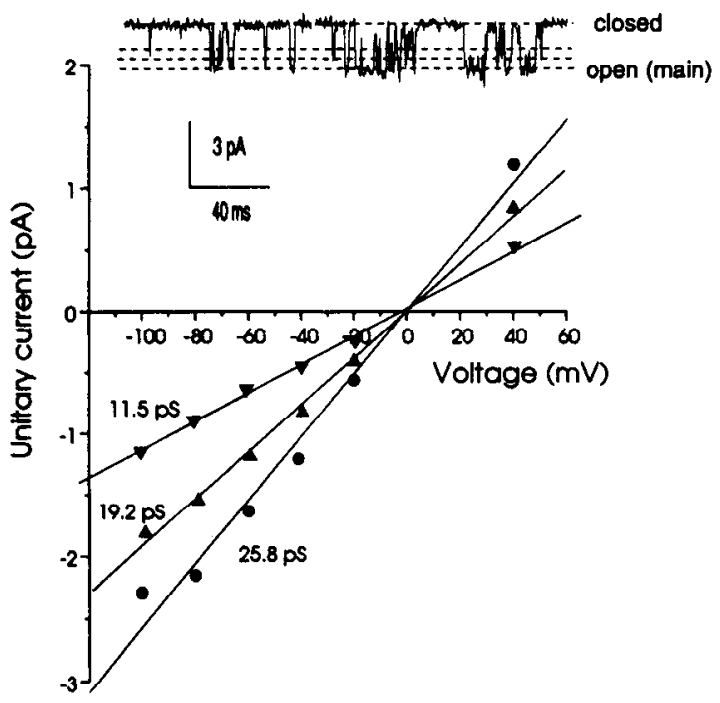

B

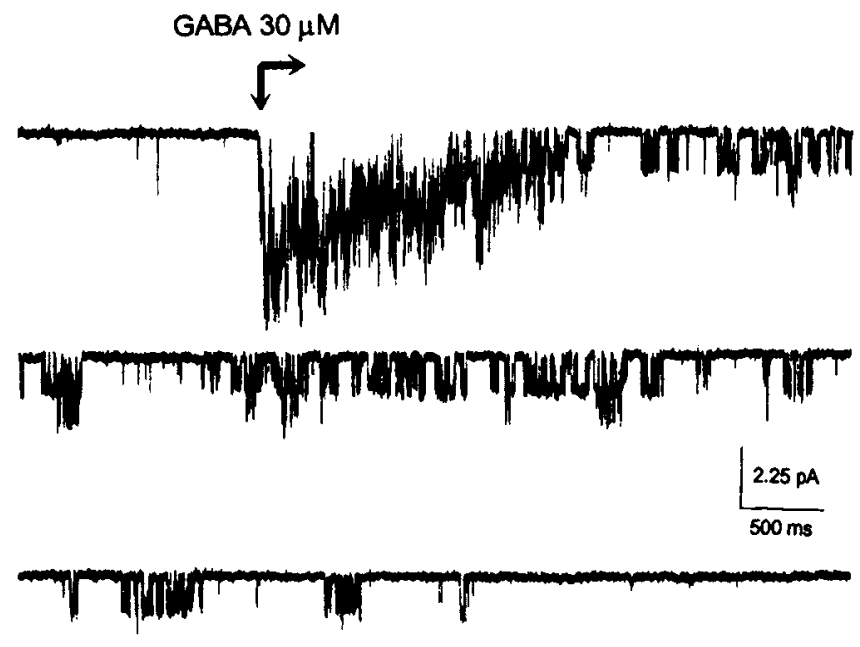

Figure 6. Properties of GABA channels in outside-out patches from cells of aged rats. $A$, Subconductance states of the GABA channel are shown with dashed lines approximating the different current levels $\left(V_{h}\right.$ $=-80 \mathrm{mV}$ ). The graph below plots unitary current versus holding voltage for this same cell and demonstrates slope conductances of 11.5, 19.2 , and $25.8 \mathrm{pS}$. The main conductance state was $25.8 \mathrm{pS}$. B, GABAchannel desensitization with continuous $(30 \mu \mathrm{M})$ GABA application. Traces are continuous records and GABA was present continuously after the arrow. $V_{h}=-80 \mathrm{mV}$. Note the characteristic burst mode of channel activity that is similar to that described previously in other nonaged preparations.

brane surface. However, the present results do not support this possibility. A general increase in receptor density would be expected to manifest a greater current density at all agonist concentrations, but aged current densities were only larger at high conccntrations and were actually smaller at the lowest concentration $(0.3 \mu \mathrm{M})$.

Ontological changes in GABA receptor subunit composition, such as those seen during development, could be responsible for the age-related differences observed in GABA response. Functional changes during development can occur in cholinergic and glycinergic transmitter systems by substitution of receptor subunits (Mishina et al., 1986; Takahashi et al,, 1992). The functional properties of GABA receptors are dependent on the specific subunit composition (Levitan et al., 1988; Verdoorn et al., 1990; review, Macdonald and Angelotti, 1993). Thus, the altered GABA responses observed in aged neurons could be supported by changes in the receptor subunit composition that increase the efficacy of agonist at high concentrations and the actions of benzodiazepines. Possible subunit changes in GABA receptors of aged neurons might be expected to alter the single-channel activity or ion specificity. Indeed, changes in single-channel conductance or open time would be a likely explanation for changes in whole-cell currents; however, no changes in single channel kinetics were detected (see below). Likewise, no change in the reversal potential for $\mathrm{Cl}^{-}$was observed. The predicted and calculated reversal potentials for the whole-cell currents were not different (Table 1). These results are in contrast to developmental changes in $\mathrm{GABA}_{\mathrm{A}}$ receptor function where the reversal potential for $\mathrm{Cl}^{-}$shifts from depolarizing in neonatal neurons to hyperpolarizing in mature cells (Cherubini et al., 1991).

No universal theory regarding age-related changes in GABA function currently exits. However, changes in receptor subunit composition with age could be of principal importance. Mhatre and Ticku (1992) reported a specific decline in mRNA levels for the $\alpha 1$ subunit (not the $\alpha 2$ or $\alpha 3$ ) in cerebral cortex with age but an increased $\alpha 6$ mRNA level in aged cerebellum. These data suggest a selective rearrangement of subunits that may not be reflected in a receptor binding study. Our results, showing an increased efficacy with no change in affinity or cooperativity, are consistent with previous reports of alterations in GABA receptor functioning without change in binding parameters (Lippa et al., 1981). Switching of receptor subunits could explain such results, in which there is no change in receptor binding but a change in receptor efficacy. For example, decreasing $\alpha 1$ relative to $\alpha 3$ subunits could result in no net change in receptor binding but an increased efficacy (Pritchett and Seeburg, 1991; Puia et al., 1991).

It is well known that the subunit composition dictates the pharmacology (Levitan et al., 1988; Pritchett et al., 1989). Our data, showing an enhanced benzodiazepine response in aged cells, is consistent with an interpretation of altered subunit composition. The enhancement was specific, since no age-related change was seen with the other allosteric modulators. An agerelated increase in benzodiazepine efficacy has been reported in clinical studies (Greenblatt et al., 1989) and in vivo rodent studies (Barnhill et al., 1990). Our results are also supported by earlier findings of an increased efficacy independent of any change in benzodiazepine binding parameters (Ruano et al., 1991; Suhara et al., 1993).

The heterogeneity of the $\mathrm{GABA}_{\mathrm{A}}$ receptor has been confirmed (Schönrock and Bormann, 1993). Results of our study also demonstrate heterogeneity of GABA responses in both young and aged neurons. Variation in receptor subunit composition between cells could be reflected in the heterogeneity of GABA responses observed. Also, part of the GABA receptor heterogeneity could be due to differences in posttranslational processing of the same subunit (Sivilotti and Nistri, 1991).

Age-related changes in second-messenger or intracellular regulatory systems could also be responsible for the changes observed in the present study. It has been known for some time 
A

$B$

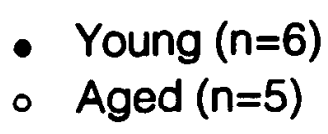

Young

Aged

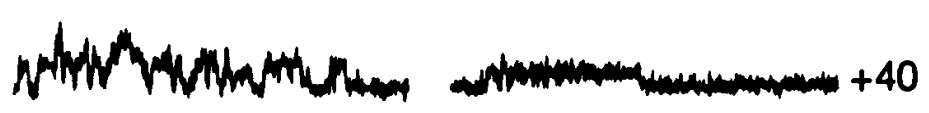

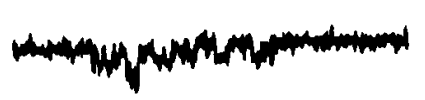

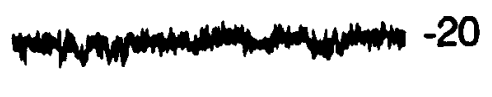

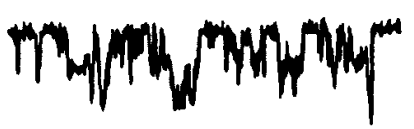

$3 \mathrm{pA}$

$40 \mathrm{~ms}$
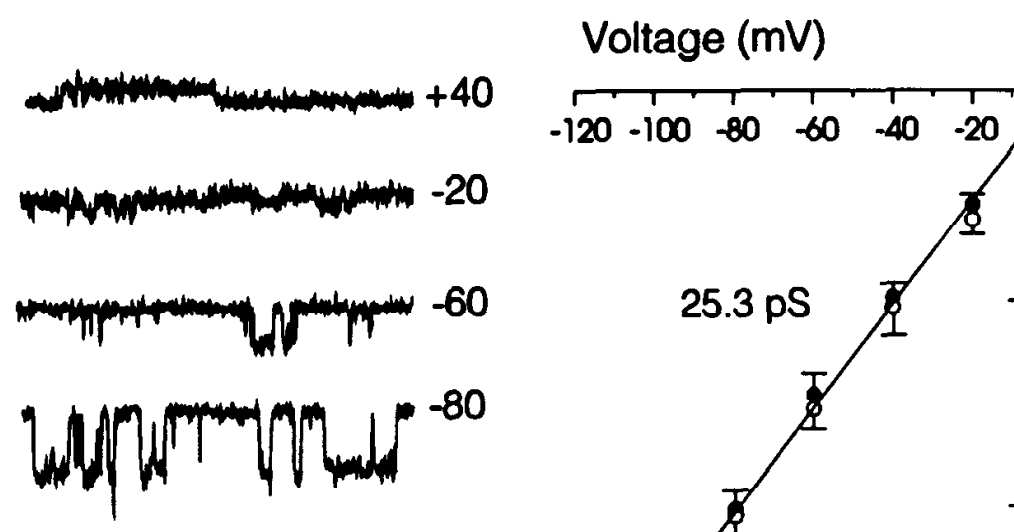

$2040 \quad 60$

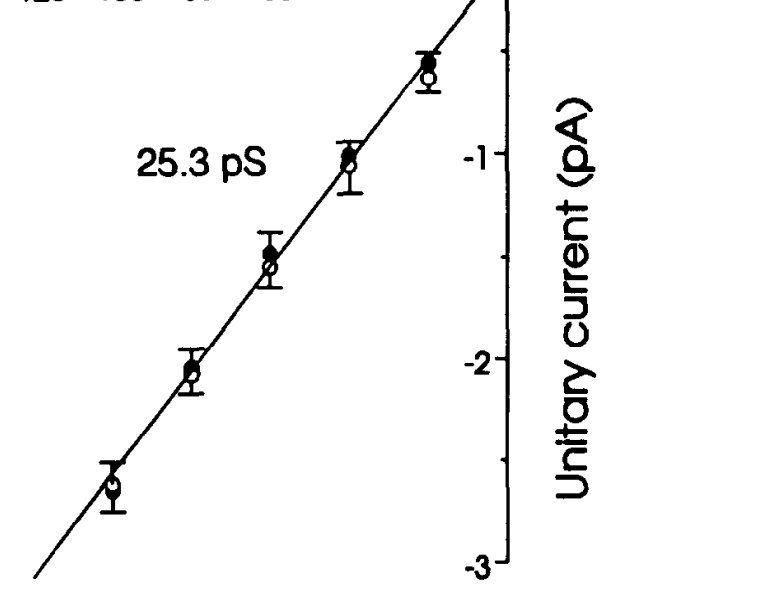

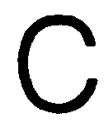

$\mathrm{D}$
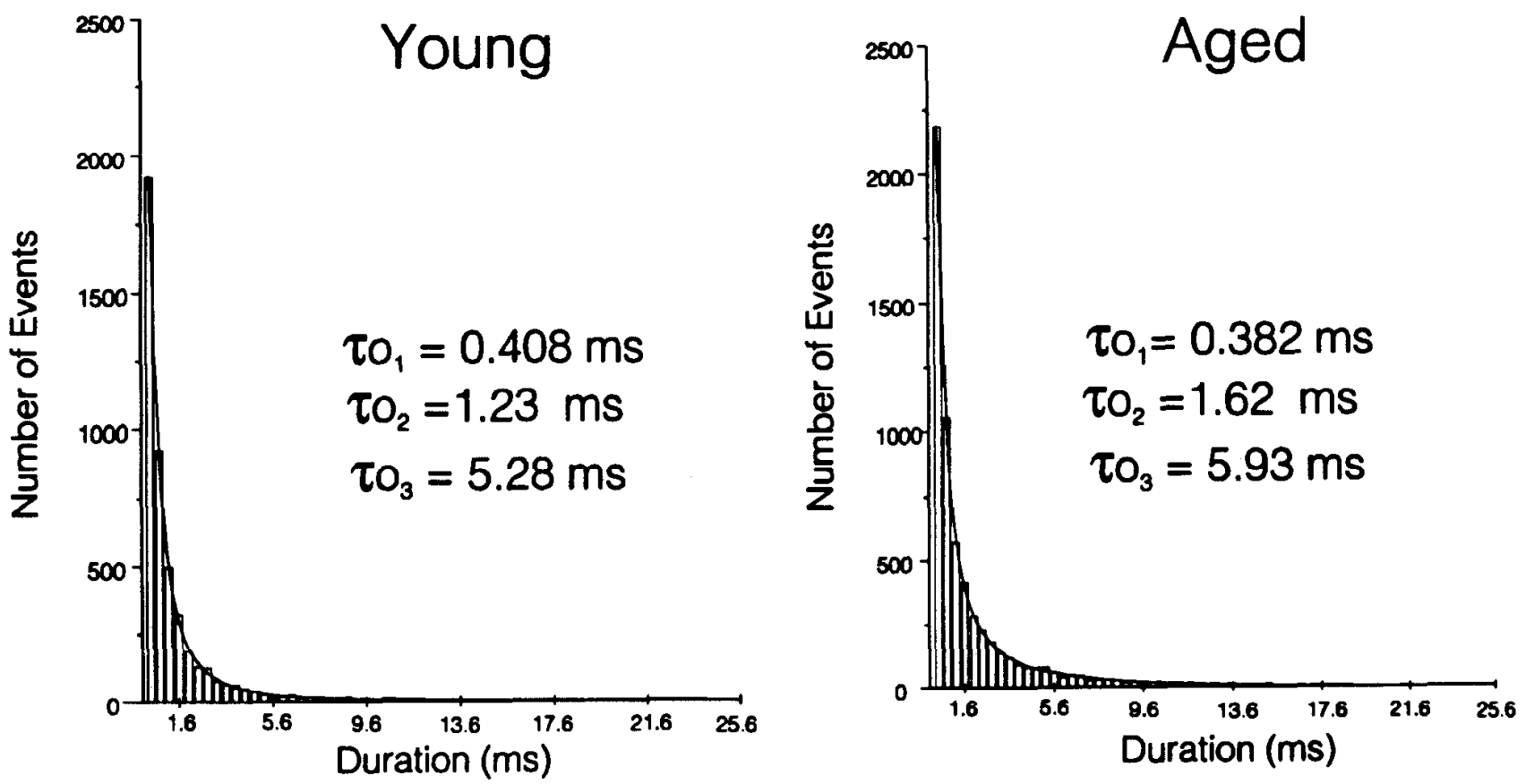

Figure 7. Properties of single GABA channels in cells from young (1-3 month) and aged (24-25 month) rats. $A$, Unitary GABA currents from patches taken from cells from 2-month (young) and 25-month (aged) rats. Patch potential shown to the right. All patches were exposed to $0.3 \mu \mathrm{M}$ GABA. $B$, Unitary GABA current versus patch potential graph for young (1-3-month) and aged (24-25-month) cells. Values are mean \pm SE for 
that second-messenger systems may influence GABA-mediated currents (Gyenes, et al., 1988; Stelzer et al., 1988). The catalytic subunit of protein kinase A (cPKA), applied intracellularly, decreased whole-cell GABA currents (Porter et al., 1990) and decreased the rapid phase of receptor desensitization (Moss et al., 1992). I ikewise, PKC phosphorylation has been shown to differentially modulate $\mathrm{GABA}_{\mathrm{A}}$ receptor function in both recombinant and native receptors (Krishek et al., 1994). Our demonstration that slow desensitization is reduced in aged cells raises the possibility that there is an alteration in the regulation of phosphorylation of the GABA receptor in medial septum/nucleus of the diagonal band neurons.

\section{Single-channel currents}

No age-related changes were observed in the properties of single GABA-activated channels when recorded in out-side out patches. Single-channel conductance, $\mathrm{Cl}^{-}$dependence and open time kinetics were similar between age groups (Table 1). Furthermore, the properties of basal forebrain GABA-activated channel currents were similar to those described previously for the GABA channel, including multiple conductance states, rapid channel desensitization, and complex open time kinetics (Hamill et al., 1983; Gray and Johnston, 1985; Bormann et al., 1987; see review, Macdonald and Olson, 1994). These observations support the notion that GABA channel activity retains similarities across cell types, despite possible subunit composition differences.

\section{Physiological significance}

Cells of the medial septum/nucleus of the diagonal band provide a substantial cholinergic input to the hippocampus (Fibiger, 1982), and alterations in the inhibitory regulation of these cells by GABA could profoundly affect hippocampal systems regulated by the septo-hippocampal pathway. Since many cells of the medial septum/nucleus of the diagonal band are themselves GABAergic (Panula et al., 1984), an increased responsiveness to GABA in these cells would have implications for both local inhibitory circuits and inhibitory outputs (Freund and Antal, 1988). Aging has been associated with a loss of GABAergic cells in the medial septum/nucleus of the diagonal band (Miettinen et al., 1993). It is thus possible that the observed increase in GABA response is triggered as a compensatory mechanism in aged cclls, although it is unknown whether this increase has a positive or negative effect in vivo. Interestingly, chronic administration of the benzodiazepine antagonist flumazenil prolonged life-span and protected rats against age-related cognitive loss (Marczynski et al., 1994), suggesting enhanced GABAergic and/or endogenous benzodiazepine activity may produce deleterious effects in the aging brain.

\section{References}

Aguayo LG, Alarcon JM (1993) Modulation of the developing rat sympathetic $\mathrm{GABA}_{\mathrm{A}}$ receptor by $\mathrm{Zn}^{++}$, benzodiazepines, barbiturates and ethanol. J Pharmacol Exp Ther 267:1414-1422.

Banay-Schwartz M, Lajtha A, Palkovitis M (1989) Changes with aging in the levels of amino acids in rat CNS structural elements. I. Glutamate and related amino acids. Neurochem Res 14:55-562.

Barnhill JG, Greenblatt DJ, Miller LG, Gaver A, Harmatz S, Shader RI
(1990) Kinetic and dynamic compounds of increased benzodiazepine sensitivity in aging animals. J Pharmacol Exp Ther 253:1153-1161.

Ben-Ari Y, Cherubini EA, Krnjevic K (1988) Changes in voltage dependence of NMDA currents during development. Neurosci Lett 94: $88-92$.

Bormann J (1988) Electrophysiology of $\mathrm{GABA}_{\mathrm{A}}$ and $\mathrm{GABA}_{\mathrm{B}}$ receptor subtypes. Neuroscience 11:112-116.

Bormann J, Hamill OP, Sakmann B (1987) Mechanism of anion permeation through channels gated by glycine and $\gamma$-aminobutyric acid in mouse cultured spinal neurons. J Physiol (Lond) 385:243-286.

Carpenter MK, Parker I, Miledi R (1992) Messenger RNAs coding for receptors and channels in the cerebral cortex of adult and aged rats. Mol Brain Res 13:1-5.

Chen QX, Stelzer A, Kay AR, Wong RKS (1990) GABA A receptor function is regulated by phosphorylation in acutely dissociated guinca-pig hippocampal ncurons. J Physiol (Lond) 420:207-221.

Cherubini E, Gaiarsa JL, Ben-Ari Y (1991) GABA: an excitatory transmitter in early postnatal life. Trends Neurol Sci 14:515-519.

Concas A, Toffano G, Biggio G (1988) Aging reduces the GABA dependent ${ }^{36} \mathrm{Cl}$-influx in rat brain membrane vesicles. Life Sci 43: 1761-1771.

Decker MW (1987) The effects of aging on hippocampal and cortical projections of the forebrain cholinergic system. Brain Res Rev 12: $423-438$

Erdo SL, Wolff JR (1989) Age-related loss of t- ${ }^{35}$ S]butylbicyclophosphorothionate binding to the gamma-aminobutyric acid receptorchloride ionophore in rat cerebral cortex. J Neurochem 53:648-651.

Fibiger HC (1982) The organization of some projections of cholinergic neurons of the mammalian forebrain. Brain Res 4:327-388.

Fischbach GD, Schultze SM (1980) A post-natal decrease in acctylcholine channel open time at rat end-plates. J Physiol (Lond) 303: $125-137$.

Freund TF, Antal M (1988) GABA-containing neurons in the septum control inhibitory interneurons in the hippocampus. Nature $336: 170$ 173.

Gambarana C, Beattie CE, Rodriguez ZR, Siegel RE (1991) Regionspecific expression of messenger RNAs encoding $\mathrm{GABA}_{\mathrm{A}}$ receptor subunits in the developing rat brain. Neuroscience 45:423-432.

Garcia R, Jaffard R (1993) A comparative study of age-related changes in inhibitory processes and long-term potentiation in the lateral septum of mice. Brain Res 620:229-236.

Gray R, Johnston D (1985) Rectification of single GABA-gated chloride channels in adult hippocampal neurons. J Neurophysiol 54:134142 .

Greenblatt DJ, Shader RI, Harmatz JS (1989) Implications of altered drug disposition in the elderly: studies of benzodiazepines. J Clin Pharmacol 29:866-872.

Griffith WH (1988) Membrane properties of cell types within guinea pig basal forebrain nuclei in vitro. J Neurophysiol 59:159-1612.

Gyenes M, Farrant M, Farb DH (1988) "Run-down" of $\gamma$-aminobutyric acid. A receptor function during whole-cell recording: a possible role for phosphorylation. Mol Pharmacol 34:719-723.

Hamill OP, Marty A, Neher E, Sakmann B, Sigworth FJ (1981) Improved patch clamp techniques for high-resolution current recording from cells and cell free patches. Pfluegers Arch 391:85-100.

Hamill OP, Bormann J, Sakmann B (1983) Activation of multipleconductance state chloride channels in spinal neurones by glycine and GABA. Nature 305:805-808.

Hestrin S (1992) Developmental regulation of NMDA receptor-mediated synaptic currents at a central synapse. Nature 357:686-689.

Kay AR, Wong RKS (1986) Isolation of neurons suitable for patchclamping from adult mammalian central nervous systems. J Neurosci Methods 16:227-238.

Kim HY, Sapp DW, Olsen RW, Tobin AJ (1993) GABA alters GABA receptor mRNAs and increases ligand binding. $J$ Neurochem 61: 2334-2337.

Kleckner NW, Dingledine R (1991) Regulation of hippocampal NMDA receptors by magnesium and glycine during development. Mol Brain Res 11:151-159.

$\leftarrow$

each age group. No change in slope conductance $(25.3 \mathrm{pS}$ ) or reversal potential was observed. ( $C$ and $D$ ) Open time histograms for three patches taken from both young (C, 1-3 month) and aged ( $D, 24-25$ month) cells. Each histogram was best fit by three time constants. Histogram in $C$ had 4772 events and $D$ had 6158 events. 
Krishek BJ, Xie X, Blackstone C, Huganir RL, Moss SJ, Sart TG (1994) Regulation of $\mathrm{GABA}_{\mathrm{A}}$ receptor function by protein kinase $\mathrm{C}$ phosphorylation. Neuron 12:1081-1095.

Laurie DJ, Wisden W, Seeburg PH (1992) The distribution of thirteen $\mathrm{GABA}_{\mathrm{A}}$ receptor subunit mRNAs in the rat brain. III. Embryonic and postnatal development. J Neurosci 12:4151-4172.

Levitan ES, Schofield PR, Burt DR, Rhee LM, Wisden W, Kohler M, Fujita N, Rodriguez HF, Stephenson A, Darlison MG; Barnard EA, Seeburg PH (1988) Structural and functional basis for GABA receptor heterogeneity. Nature 335:76-79.

Lippa AS, Critchett DJ, Ehlert F, Yamamura HI, Enna SJ, Bartus RT (1981) Age-related alterations in neurotransmitter receptors: an electrophysiological and biochemical analysis. Neurobiol Aging 2:3-8.

Luhmann HJ, Prince DA (1991) Postnatal maturation of the GABAergic system in rat neocortex. J Neurophysiol 65:247-263.

Macdonald RL, Angelotti TP (1993) Native and recombinant GABA receptor channels. Cell Physiol Biochem 3:352-373.

Macdonald RL, Olson RW (1994) GABA A receptor channels. Annu Rev Neurosci 17:569-602.

Marczynski TJ, Artwohl J, Marczynska B (1994) Chronic administration of flumazenil increases life span and protects rats from agerelated loss of cognitive functions: a benzodiazepine/GABA hypothesis of brain aging. Neurobiol Aging 15:69-84.

Mhatre MC, Ticku MK (1992) Aging related alterations in GABA receptor subunit mRNA levels in Fischer rats. Mol Brain Res 14:7178.

Miettinen R, Sirvio J, Riekkinen P Sr, Laakso MP, Riekkinen P Jr (1993) Neocortical hippocampal and septal parvalbumin- and somatostatin-containing neurons in young and aged rats: correlation with passive avoidance and water maze performance. Neuroscience $53: 367-378$

Mishina M, Takai T, Imoto K, Noda M, Takahashi T, Numa S, Methfessel C, Sakmann B (1986) Molecular distinction between fetal and adult forms of muscle acetylcholine receptor. Nature 321:406-411.

Moss SJ, Smart TG, Blackstone CD, Huganir RL (1992) Functional modulation of $\mathrm{GABA}_{\mathrm{A}}$ receptors by $\mathrm{CAMP}$-dependent protein phosphorylation. Science 257:661-665.

Mueller AL, Taube JS, Schwartzkroin PA (1984) Development of hyperpolarizing inhibitory postsynaptic potentials and hyperpolarizing response to $\gamma$-aminobutyric acid in rabbit hippocampus studied in vitro. J Neurosci 4:860-867.

Panula P, Revielta AV, Chenery DL, Wu J-Y, Costa E (1984) An immunohistochemical study on the location of GABAergic neurons in the rat septum. J Comp Neurol 222:69-80.

Porter NM, Twyman RE, Uhler MD, Macdonald RL (1990) Cyclic AMP-dependent protein kinase decreases $\mathrm{GABA}_{\mathrm{A}}$ receptor current in Inouse spinal neurons. Neuron 5:789-796.

Potier B, Rascol F, Jazat F, Lamour Y, Dutar P (1992) Alterations in the properties of hippocampal pyramidal neurons in the aged rat. Neuroscience 48:793-806.

Pritchett DB, Seeburg PH (1991) $\gamma$-Aminobutyric acid type A receptor point mutation increases the affinity of compounds for the benzodiazepine site. Proc Natl Acad Sci USA 88:1421-1425.

Pritchett DB, Luddens H, Seeburg PH (1989) Type I and Type II GA$\mathrm{BA}_{\mathrm{A}}$-benzodiazepine receptors produced in transfected cells. Science 245:1389-1392.

Puia G, Vicini S, Seeburg PH, Costa E (1991) Influence of recombinant $\gamma$ - aminobutyric acid- ${ }_{A}$ receptor subunit composition on the action of allosteric modulators of $\gamma$-aminobutyric acid-gated $\mathrm{Cl}^{-}$currents. Mol Pharmacol 39:691-696.

Rovira C, Ben-Ari Y (1993) Developmental study of benzodiazepine effects on monosynaptic $\mathrm{GABA}_{\mathrm{A}}$-mediated IPSPs of rat hippocampal neurons. J Neurophysiol 70:1076-1994.

Ruano DJ, Cano A, Machado A, Vitorica J (1991) Pharmacologic characterization of $\mathrm{GABA}_{\mathrm{A}}$ /benzodiazepine receptor in rat hippocampus during aging. J Pharmacol Exp Ther 256:902-908.

Sakmann B, Brenner HR (1978) Change in synaptic channel activity during neuromuscular development. Nature 276:401-402.

Schönrock B, Bormann J (1993) Functional heterogeneity of hippocampal GABA receptors. Eur J Neurosci 5:1042-1049.

Sivilotti L, A Nistri (1991) GABA receptor mechanisms in the central nervous system. Prog Neurobiol 36:35-92.

Smart TG (1992) A novel modulatory binding site for zinc on the $\mathrm{GABA}_{\mathrm{A}}$ receptor complex in cultured rat neurones. J Physiol (Lond) 447:587-625.

Smart TG, Constanti A (1990) Differential effect of zinc on the vertebrate GABA -receptor complex. Br J Pharmacol 99:643-654.

Stelzer A, Kay AR, Wong RKS (1988) GABA -receptor function in hippocampal cells is maintained by phosphorylation. Science 241 : 339-341.

Suhara T, Inoue O, Kobayashi K, Suzuki K, Itoh T, Tateno Y (1993) No age-related changes in human benzodiazepine receptor binding measured by PET with [ $\left.{ }^{11} \mathrm{C}\right]$ Ro $15-4513$. Neurosci Lett 159:207-210.

Takahashi T, Momiyama A, Hirai K, Hishinuma F, Akayi H (1992) Functional correlation of fetal and adult forms of glycine receptors with developmental changes in inhibitory synaptic receptor channels. Neuron 9:1155-1161.

Tsumoto T, Hagihara K, Sato H, Hata Y (1987) NMDA receptors in the visual cortex of young kittens are more effective than those of adult cats. Nature 327:513-514.

Verdoorn TA, Draguhn A, Ymer S, Seeburg PH, Sakmann B (1990) Functional properties of recombinant rat $\mathrm{GABA}_{\mathrm{A}}$ receptors depend upon subunit composition. Neuron 4:919-928.

Wenk GL, Walker LC, Price DL, Cork LC (1991) Loss of NMDA, but not $\mathrm{GABA}_{\mathrm{A}}$, binding in the brains of aged rats and monkeys. Neurobiol Aging 12:93-98.

Zhang J-H, Sato M, Araki T, Tohyama M (1992) Postnatal ontogenesis of neurons containing $\mathrm{GABA}_{\mathrm{A}}$ al subunit mRNA in the rat forebrain. Mol Brain Res 16:193-203.

Zhang L, Spigelman I, Carlen PL (1991) Development of GABA-mediated chloride-dependent inhibition in CAl pyramidal neurones of immature rat hippocampal slices. J Physiol (Lond) 444:25-49. 